\title{
Allogenic Bone Marrow Transplantation in Severe Gaucher Disease
}

\author{
PHILIP TSAI, JEFFREY M. LIPTON, INDIRA SAHDEV, VESNA NAJFELD, LINDA R. RANKIN, \\ ARNOLD H. SLYPER, MARK LUDMAN, AND GREGORY A. GRABOWSKI
}

\begin{abstract}
Department of Pediatrics, Division of Pediatric Hematology/Oncology, Bone Marrow Transplantation Unit, Mount Sinai School of Medicine [P.T., J.M.L.]; Department of Pediatrics, Bone Marrow Transplantation Unit, North Shore University Hospital, Cornell University Medical College, Manhassett, New York [I.S.] 11030; Department of Medicine, Tumor Cytogenetics, Polly Annenberg Hematology Center, Mount Sinai School of Medicine [V.N.]; Department of Pathology. St. Joseph's Hospital [L.R.R.] and Division of Pediatric and Adolescent Endocrinology and Metabolism, St. Joseph's Hospital and Medical Center [A.H.S.], Paterson, New Jersey 07503; and Division of Medical and Molecular Genetics, Mount Sinai School of Medicine,
\end{abstract} New York, New York 10029 [M.L., G.A.G.]

\begin{abstract}
Gaucher disease is the most prevalent lysosomal storage disease. This autosomal recessive disease is caused by the defective activity of the enzyme acid $\beta$ glucosidase and the resultant accumulation of glucosylceramide primarily within cells of the reticuloendothelial system. Because the primary manifestations of Gaucher disease are due to involvement of monocyte/macrophagederived cells, this disease is thought to be an excellent candidate for curative intervention via bone marrow transplantation (BMT). A Hispanic female with subacute neuronopathic Gaucher disease and rapidly progressing visceral manifestations underwent BMT at 23 mo of age using her histocompatible normal brother as the donor. Cytogenetic analyses demonstrated complete, stable engraftment by 1 mo post-BMT. During the subsequent 24 mo, clinical, biochemical, enzymatic, and histologic studies demonstrated nearly complete correction in the viscera. Her neuropathic manifestations did not progress. Complete reconstitution of enzymatic activity in peripheral blood leukocytes was achieved by 1 mo. Cytogenetic analyses demonstrated complete engraftment by $d 79$ and nearly complete loss of bone marrow Gaucher cells was observed by 8 mo. Plasma glucosylceramide levels normalized by 8-12 mo. Nearly coincident improvements in hepatic size, enzyme levels, and histology were found by 12-24 mo postBMT. Fatal sepsis occurred at 24 mo post-BMT. Autopsy revealed sparse Gaucher cells in clusters in the liver, lymph nodes, and lungs as well as the lack of periadventitial Gaucher cells surrounding brain vessels. The findings provide the time course and rationale for studies directed to gene therapy via BMT for this disease after introduction of acid $\beta$-glucosidase gene constructs into autologous pluripotent stem cells of selected Gaucher disease patients. (Pediatr Res 31: 503-507, 1992)
\end{abstract}

Abbreviations

BMT, bone marrow transplantation

Received November 21, 1991; accepted January 9, 1992.

Correspondence: Gregory A. Grabowski, M.D., Professor of Pediatrics and Genetics, Mount Sinai School of Medicine, One Gustav L. Levy Place, New York, NY 10029.

Supported by grants from the National Institutes of Health (DK36729 to G.A.G.), the March of Dimes National Birth Defects Foundation (1-857 to G.A.G.), and the Division of General Clinical Research Resources of the National Institutes of Health (RR-71) and the Ruth Turner Fund and the Harvey Abrams Memorial Branch Cancer Research Fund.
Gaucher disease is the most prevalent lysosomal storage disease (1) and the most frequent genetic disease in the Ashkenazi Jewish population (2). This autosomal recessive disorder of glycosphingolipid metabolism results from numerous point mutations at the locus-encoding acid $\beta$-glucosidase (glucocerebrosidase) (for review, see Ref. 3). The majority of these are missense mutations, which lead to the defective activity of this enzyme (3-5). The resultant accumulation of the substrate, glucosylceramide, within monocyte/macrophage-derived cells (Gaucher cells) leads to the visceral manifestations including hepatosplenomegaly, hypersplenism, and skeletal disease (6). Three variants of the disease have been delineated based on the absence (type 1, nonneuronopathic) or presence (neuronopathic) and severity (type 2, acute; type 3 subacute) of primary CNS involvement (6). Because the major visceral manifestations of this disease result from the accumulation of bone marrow-derived tissue-bound macrophages, Gaucher disease type 1 has been a prime candidate for curative intervention by BMT. In addition, demonstration of the clinical, biochemical, and histopathologic efficacy of BMT would provide the basis for ongoing efforts directed toward molecular therapy for this disease.

Previously, Rappeport and Ginns (7), Hobbs et al. (8), and Erickson et al. (9) demonstrated engraftment of bone marrow transplanted from histocompatible siblings into affected patients. In the case of Rappeport and Ginns, the advanced stage of the disease precluded assessments of clinical or biochemical effects beyond $1 \mathrm{y}$. The six less severely involved patients reported by Hobbs et al. (8) apparently improved and are doing well several years after engraftment. The cases described by Erickson et al. (9) were three children with the Norbottnian variant of type 3 Gaucher disease, and they have stable neurologic status after BMT. Recently, enzyme augmentation has been clearly demonstrated to reverse many of the major visceral manifestations of Gaucher disease (10-13). Thus, the latter provides an effective, safe (albeit very expensive) treatment, whereas BMT may provide a more risky curative cellular replacement approach.

Lacking an animal model for Gaucher disease, extensive tissue analyses of histologic improvement and enzyme reconstitution have not been available for either therapeutic strategy. Fatal Streptococcus pneumoniae sepsis resulted in the unfortunate death of a Gaucher disease patient 24 mo after uneventful histocompatible BMT. The serial analyses of this patient provide clinical, biochemical, and histologic evidence as well as a time course for improvement in this Hispanic type 3 , subacute neuronopathic, Gaucher disease patient over a 2-y period. 


\section{METHODS AND MATERIALS}

Materials. The following were from commercial sources: 4methylumbelliferyl- $\beta$-D-glucopyranoside (Genzyme Corp., Boston, MA); 12[N-methyl-N-(7-nitrobenz-2-oxa-1,3-diazol-4-yl)] dodecanoic acid (Molecular Probes, Junction City, OR); and sodium taurocholate (Calbiochem, San Diego, CA). All other reagents were of the highest available grade. $\mathrm{C}_{12}$-NBD-glucosylceramide (NBD-GC) was prepared and purified as described (14). Natural glucosylceramide was purified from Gaucher disease splenic extracts and glucosylsphingosine was prepared as described (14).

Informed consent for BMT as well as tissue samples were obtained according to institutional and National Institutes of Health guidelines. Blood, bone marrow, skin, and liver specimens were obtained by routine procedures.

Methods. Tissue specimens. Mononuclear cells were isolated from peripheral blood by routine methods (14). The washed pellets were frozen at $-20^{\circ} \mathrm{C}$ until use. Liver specimens were obtained by needle biopsy and quick frozen on dry ice. The specimens were kept frozen at $-80^{\circ} \mathrm{C}$ in tightly sealed tubes until used. Autopsy specimens of brain, liver, lung, kidney, and lymph node were obtained within $7 \mathrm{~h}$ of death, quick frozen, and stored at $-80^{\circ} \mathrm{C}$ until assayed. Control normal and Gaucher disease tissues were obtained at autopsy within $2-10 \mathrm{~h}$ of death, quick frozen, and stored in tightly sealed tubes at $-80^{\circ} \mathrm{C}$. Chromosome analyses of bone marrow specimens and phytohemagglutininstimulated peripheral blood cells were conducted according to established protocols (15).

Enzymatic and biochemical analyses. Acid $\beta$-glucosidase activities in peripheral blood leukocytes and tissue extracts were determined with the 4-methylumbelliferyl- $\beta$-D-glucopyranoside and NBD-GC, substrates as described $(4,14)$. The results are reported as the average of triplicate determinations. Protein concentrations were determined by the Lowry method (16). Plasma glucosylceramide and globotriaocylceramide concentrations were determined by reversed phase HPLC as described (17). For these determinations, $1-\mathrm{mL}$ aliquots of plasma were frozen in tightly sealed tubes at $-80^{\circ} \mathrm{C}$. The concentrations are reported as the means of duplicate determinations from two separate assays. Normal values were obtained from pooled lots of outdated pooled human fresh frozen plasma from at least 10 normal individuals.

Clinical assessments. Serial volumes of the liver were quantitated by established computed tomographic techniques $(18,19)$. Computed tomography and magnetic resonance imaging scans of the brain were conducted according to routine procedures. ${ }_{99 \mathrm{~m}} \mathrm{Tc}$-sulfur colloid scans were conducted according to our procedure to avoid artifactual diminution in marrow activity in Gaucher disease due to liver, lung, and splenic uptake (20). Psychomotor evaluations were conducted using the Bayley Scales of Infant Development and the Merrill-Palmer Scale of Mental tests in a friendly environment by the same individual who had established rapport with the patient.

\section{CASE REPORT}

After an uneventful pregnancy and delivery, this Hispanic female was healthy until 7 mo of age when hepatosplenomegaly was found. Developmental milestones were normal until 7-9 mo of age. Progressive visceral enlargement and growth retardation as well as anemia and thrombocytopenia led to a bone marrow examination at 13 mo of age. Large numbers of Gaucher cells were found. On presentation to the Mount Sinai School of Medicine at 18 mo of age, she was cachectic, the liver was $\sim 10$ $\mathrm{cm}$ below the right costal margin in the mid-clavicular line and the spleen extended across the midline and into the pelvis. Also present was severe failure to thrive (height $<3 \mathrm{rd}$ percentile, occipital frontal circumference $=50$ th percentile). Although her weight was at the 50th percentile for age, the spleen constituted about $12 \%$ of her body weight as determined from the weight of the removed spleen. Mild respiratory distress with intercostal retractions also was present. The mechanical interference with breathing and severe anemia and thrombocytopenia provided the rationale for a subtotal splenectomy at $18 \mathrm{mo}$ of age. Pneumovax and Haemophilus influenzae $\mathrm{B}$ vaccine were administered 2 wk before the removal of about $85 \%$ of the splenic mass. However, within $3 \mathrm{mo}$, rapidly progressive visceral Gaucher disease was evidenced by regrowth of the splenic remnant to $10 \%$ of body weight $(21)$, pulmonary involvement $\left[\mathrm{PO}_{2}\right.$ decreased from 97 to $65 \mathrm{~mm} \mathrm{Hg}$ (13 to $9 \mathrm{kPa}$ )], hepatic enlargement (liver extending into the pelvis), and redevelopment of hypersplenism with anemia and thrombocytopenia. These provided the rationale for BMT at 24 mo of age. At that time, she had severe failure to thrive, moderate developmental delay (Table 1), an abnormal EEG with an irritative pattern, and mild cerebral atrophy by computed tomography and magnetic resonance imaging scans. Normal eye movements had been found by neuroophthalmologic exam within 3 mo before BMT. She had a completion splenectomy 1 mo before BMT. One mo before BMT, she developed strabismus due to supranuclear VI cranial nerve palsy. Her normal brother was an HLA homozygous identical match at the $\mathrm{A}, \mathrm{B}$, and $\mathrm{D}$ loci and was nonreactive by the mixed lymphocyte reaction. He had normal (noncarrier) acid $\beta$-glucosidase activities in his peripheral blood mononuclear cells and in cultured skin fibroblasts. After anti-thymocyte globulin, busulfan, and cyclophosphamide induction according to standard protocols $(22)$, she received an infusion of $7.3 \times 10^{8}$ bone marrow mononuclear cells $/ \mathrm{kg}$ body weight from her donor brother. Methotrexate prophylaxis for graft versus host disease was given on $\mathrm{d} 1,3,7$, and 11, and i.v. Ig was administered every 4 wk for six doses. After an uneventful course, she was discharged on d 30. At no time was graft versus host disease detected. She experienced several bouts of bilateral pneumonia during the period from 18 to 21 mo after BMT. Ig levels, lymphocyte number and subsets (23), mitogen stimulation, and tetanus toxoid levels were normal at the time. She was not reimmunized with Pneumovax and was maintained on daily oral penicillin. She experienced fatal $S$. pneumoniae sepsis on d 735 post-BMT. Quick frozen as well as fixed tissues were obtained for biochemical and histologic analyses within about $7 \mathrm{~h}$ of death.

\section{RESULTS}

Clinical evaluations and histologic evaluations. Before BMT, the patient had severe failure to thrive, which was not alleviated by subtotal or total splenectomy. After transplantation, she maintained her weight at about the 30th to 50th percentile and her height increased from less than the 3 rd percentile to the 10 th percentile by 9 mo post-BMT and to the 50th percentile by 24 mo post-BMT. In addition, the pre-BMT cachexia disappeared by $9-12$ mo post-BMT. Serial neuropsychologic testing demonstrated a delay in development pre-BMT with a developmental quotient of 66, which did not change during the post-BMT course (Table 1). However, by $600 \mathrm{~d}$ post-BMT, she was fluently bilingual. Before BMT, her only hard neurologic signs were the strabismus and an irritative pattern on EEG. Post-BMT, the strabismus did not improve, whereas the irritative pattern on EEG disappeared by about $250 \mathrm{~d}$. Mild cerebral atrophy was noted by computed tomography and magnetic resonance imag-

Table 1. Serial neuropsychologic evaluations after BMT

\begin{tabular}{cccc}
\hline Day* & $\begin{array}{c}\text { Chronologic age } \\
(\mathrm{mo})\end{array}$ & $\begin{array}{c}\text { Mental age } \\
(\mathrm{mo})\end{array}$ & DQ† \\
\hline-164 & 18 & 12 & 66 \\
-71 & 22 & 15 & 68 \\
244 & 33 & 21 & 64 \\
418 & 39 & 25 & 64 \\
\hline
\end{tabular}

* Minus sign indicates pre-BMT day.

$+\mathrm{DQ}$, developmental quotient. 
ing brain scans before BMT, and these did not change. At autopsy, the brain was of normal weight with slightly widened sulci. Histologic examination of multiple sections of the cerebral cortex, basal ganglia, brain stem, and cerebellum did not demonstrate the presence of Gaucher-like glial cells, nor was neuronal loss noted. Periadventitial Gaucher cell accumulation was not present around CNS vessels.

Hematologic reconstitution was achieved by 1 mo after BMT. As shown by bone marrow (Table 2) cytogenetic analysis, essentially complete engraftment of the male donor bone marrow was achieved by d 79 and maintained throughout the life of the patient. Consistent with the prolonged life of $T$ lymphocytes, peripheral blood cytogenetic analysis demonstrated less than $2 \%$ female (i.e. XX) cells in PHA-stimulated lymphocytes at about $200 \mathrm{~d}$ after transplantation. In comparison, the resolution of the bone marrow involvement by Gaucher disease was slower, as determined by the percentage of Gaucher cells in iliac crest bone marrow biopsies. Nearly complete loss of Gaucher cells from these biopsies was observed by d 246 and 408 post-BMT (Table 2). In several representative bone marrow specimens from the ribs, vertebrae, and iliac crests obtained at autopsy (d 735), Gaucher cells were present in small numbers and in clusters and were randomly distributed in the marrow (data not shown). The results of ${ }^{99 m} \mathrm{Tc}$-sulfur colloid bone marrow scans were consistent with these histologic findings. Before BMT and after full engraftment at about $80 \mathrm{~d}$ post-BMT, ${ }^{99 \mathrm{~m}} \mathrm{Tc}$-sulfur colloid scans revealed decreased central marrow activity with moderate marrow extension and multiple focal defects of the femurs and humeri. On about d 420, a similar scan was completely normal with loss of the focal defects and reestablishment of normal central marrow activity.

Biochemical and enzymatic evaluations. Plasma glucosylceramide levels became consistently normal after about $\mathrm{d} 150$ postBMT (Fig. 1). From a pre-BMT mean of $15.8 \mathrm{nmol} / \mathrm{mL}$ of plasma, a nearly linear decrease was observed until after d 240 , when a plateau in the normal range was maintained. These levels correlated with the disappearance of Gaucher cells from the bone marrow (Table 2) as well as with the loss of Gaucher Kupffer cells from the liver and enzymatic reconstitution in that organ (Table 3). Serial liver biopsies demonstrated the progressive loss of Gaucher Kupffer cells [from 25\% (pre) to $<5 \%$ (at autopsy)] from the liver. Histologic examination of the liver at autopsy revealed small numbers of Gaucher cells within the portal triads. These findings were coincident with increasing levels of acid $\beta$ glucosidase activity in that organ. Pre-BMT acid $\beta$-glucosidase levels were about $11 \%$ of mean normal levels (Table 3 ). By d 419 , this had increased to a constant level of about $43 \%$ of mean normal levels.

Acid $\beta$-glucosidase levels in other tissues obtained at autopsy from the present patient, normals, and other Gaucher disease patients are shown in Table 4 . In addition to liver, the enzyme levels in lung and lymph nodes were $50-60 \%$ of mean normal levels and clearly at much greater levels than in comparable

Table 2. Bone marrow cytogenetic and histologic reconstitution after BMT in Gaucher disease

\begin{tabular}{rcc}
\hline Day & $\begin{array}{c}\text { Karyotype } \\
(\% \text { XY) }\end{array}$ & $\begin{array}{c}\text { Histology* } \\
(\% \text { Gaucher cells })\end{array}$ \\
\hline-61 & & 30 \\
15 & 50 & \\
28 & 60 & 20 \\
79 & 94 & Few scattered \\
246 & 100 & Few scattered \\
408 & & \\
665 & 100 & Scattered $\dagger$ \\
735 & & \\
\hline
\end{tabular}

* From iliac crest.

† Autopsy with small numbers of Gaucher cells in clusters in ribs, vertebrae, and iliac crests.

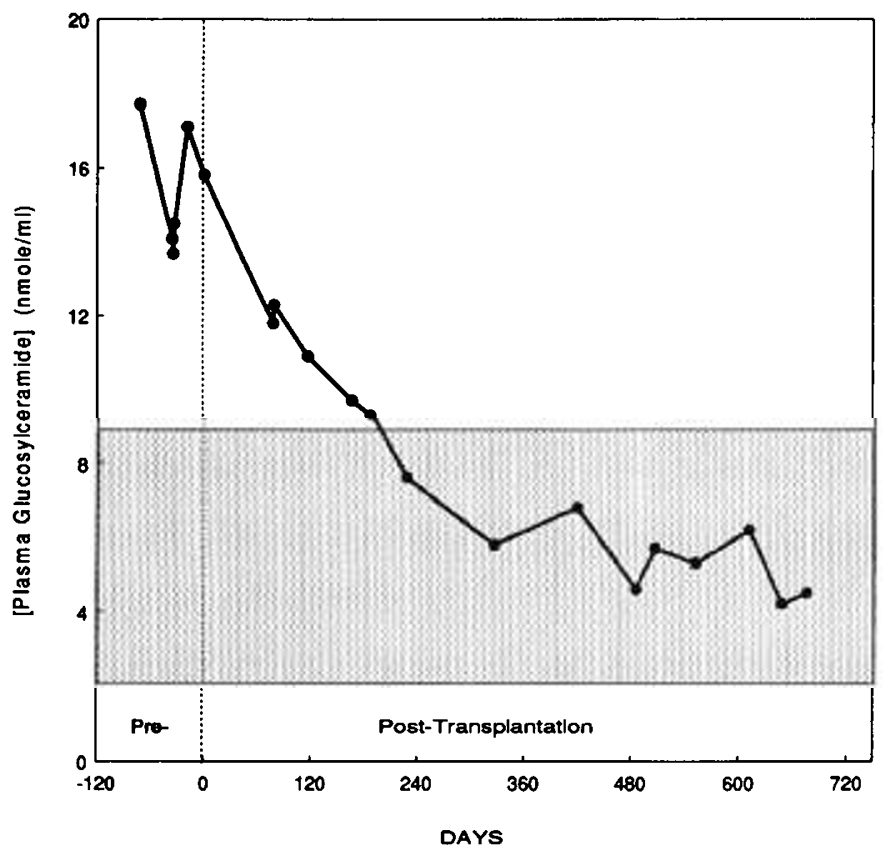

Fig. 1. Time course for plasma glucosylceramide after BMT. The shaded area represents the normal ranges obtained for pooled, outdated, fresh frozen plasma.

Table 3. Liver studies after BMT in a Gaucher disease patient

\begin{tabular}{ccccc}
\hline & & & \multicolumn{2}{c}{$\begin{array}{c}\text { Acid } \beta- \\
\text { glucosidase } \dagger \\
\text { (nmol/h/mg } \\
\text { protein) }\end{array}$} \\
\cline { 3 - 5 } $\begin{array}{cccc}\text { Day post- } \\
\text { BMT }\end{array}$ & $\begin{array}{c}\text { Volume }\left(\mathrm{cm}^{3}\right) / \\
\% \text { expected }\end{array}$ & $\begin{array}{c}\% \\
\text { Gaucher cells }\end{array}$ & GC & 4 MUGlc \\
\hline-32 & $720 / 300$ & $\sim 25$ & 9.7 & 7.8 \\
+78 & $620 / 225$ & $\sim 25$ & 10.3 & 9.9 \\
+246 & $409 / 136$ & $\sim 25$ & 15.6 & 14.9 \\
+419 & $406 / 116$ & $\sim 10$ & 29.6 & 36.6 \\
+735 & $600 / 125 \ddagger$ & $<5$ & 30.3 & 35.5 \\
\hline
\end{tabular}

* Expected weight calculated from body weight $\times 2.5 \%$ (32).

† Normal and Gaucher disease values are shown in Table 4. GC and 4MUGlc refer to glucosylceramide and synthetic $\beta$-glucoside substrates, respectively. Some assays to assess GC hydrolytic activity required 10to 50 -fold dilutions to avoid inhibition by stored glucosylceramides.

$\ddagger$ The autopsy liver was congested.

Table 4. Tissue levels of acid $\beta$-glucosidase in normals and Gaucher disease patients*

\begin{tabular}{lcccc}
\hline & $\begin{array}{c}\text { Liver } \\
(\mathrm{nmol} / \mathrm{h} \\
/ \mathrm{mg})\end{array}$ & $\begin{array}{c}\text { Lung } \\
(\mathrm{nmol} / \mathrm{h} \\
/ \mathrm{mg})\end{array}$ & $\begin{array}{c}\text { Lymph } \\
\text { node } \\
(\mathrm{nmol} / \mathrm{h} \\
/ \mathrm{mg})\end{array}$ & $\begin{array}{c}\text { Brain } \\
(\mathrm{nmol} / \mathrm{h} \\
/ \mathrm{mg})\end{array}$ \\
\hline Source $\dagger$ & & & & \\
$\begin{array}{l}\text { Patient } \\
\text { 4MUGlc }\end{array}$ & 35 & 14 & 19 & 1 \\
$\quad$ GC & 30 & 31 & 22 & 9 \\
Normal $(n=11)$ & & & & \\
$\quad$ 4MUGlc & $84 \pm 25$ & $23 \pm 9$ & $31 \pm 11$ & $61 \pm 21$ \\
GC & $71 \pm 18$ & $56 \pm 12$ & $37 \pm 9$ & $69 \pm 25$ \\
Gaucher disease & & & & \\
$\quad(n=5)$ & & & & \\
4MUGlc & $12 \pm 5$ & $0.6 \pm 0.5$ & $4 \pm 2$ & $2 \pm 1$ \\
GC & $14 \pm 7$ & $6 \pm 4$ & $3 \pm 2$ & $11 \pm 7$ \\
\hline
\end{tabular}

* Tissue samples were obtained at autopsy of normals between 2 and $24 \mathrm{~h}$ of death.

$\uparrow 4$ MUGlc and GC refer to the synthetic and glucosylceramide substrates, respectively. 
tissues from other Gaucher disease patients. This correlated well with the histologic resolution of Gaucher disease in the corresponding tissues because Gaucher cells were not found in ileocecal, peritracheal, or retroperitoneal lymph nodes. A few Gaucher cells were found in mesenteric lymph nodes. In lungs, clusters of small numbers of Gaucher cells were found in the alveolar septa and interstitium. No difference in the levels of acid $\beta$-glucosidase were found in brain specimens obtained at autopsy from the present patient and comparable specimens from other Gaucher disease patients (Table 4).

\section{DISCUSSION}

The clinical manifestations of the nonneuronopathic variants (type 1) of Gaucher disease are due almost exclusively to the effects of accumulated glucosylceramides within cells of the reticuloendothelial system (1). It is thought that the vast majority of visceral glucosylceramides which accumulate in Gaucher disease derive from leukocyte membranes, which are presented to tissue-bound macrophages for degradation (24). As such, complete replacement of monocyte/macrophage precursors with enzymatically corrected progenitors should lead to replacement of the Gaucher cells in reticuloendothelial organs and "cure" this aspect of the visceral manifestations of this disease. The present results indicate that in rapidly progressing Gaucher disease type 3, BMT from a sibling donor with normal enzymatic activity did lead to replacement of Gaucher cells by their normal counterparts in the bone marrow, liver, lung, lymph nodes, and probably, in CNS vascular periadventitial areas. Coincident with correction of the cellular defect, normalization of plasma glucosylceramide levels occurred and enzymatic reconstitution was demonstrated in serial liver biopsies and in other visceral reticuloendothelial organs at autopsy.

Serial histologic examination of bone marrow and liver indicated a differential replacement of Gaucher cells with normal macrophage derivatives in these organs. As determined by iliac crest biopsy, nearly complete clearance of bone marrow Gaucher cells occurred by about $8 \mathrm{mo}$. This histologic resolution lagged behind the replacement of mitotic bone marrow cells with male donor cells by about $6 \mathrm{mo}$. Although these studies suggested complete loss of Gaucher cells from the bone marrow, multiple specimens of bone marrow from vertebrae, ribs, and iliac crests at autopsy demonstrated the persistence of scattered rests of Gaucher cells. Similarly, by d 419 , the ${ }^{99 \mathrm{~m}} \mathrm{~T}$ c-sulfur colloid scan of the bone marrow had normalized with loss of focal uptake defects and reconstitution of central marrow activity. In comparison, the loss of Gaucher cells (Kupffer cells) from the liver was much slower, with a decrease of Gaucher cells estimated per field from 25 to $10 \%$ by $419 \mathrm{~d}$ and with about $5 \%$ remaining at $735 \mathrm{~d}$ in autopsy specimens. Although serial samples from lymph nodes and lungs were not obtained, scattered Gaucher cells were present in these tissues at autopsy $735 \mathrm{~d}$ after BMT.

The presence of Gaucher cells in the reticuloendothelial organs examined 2 y after successful uncomplicated BMT with persistent complete engraftment indicates the very long life span of the diseased macrophages in this disease. Unlike most other lysosomal enzymes, acid $\beta$-glucosidase is a membrane-associated enzyme that is not normally secreted in any appreciable amounts (3). Consequently, the loss of Gaucher cells from affected organs can only occur by replacement with normal bone marrowderived cells and turnover of the storage cells in situ. This mechanism is supported by the recent study demonstrating rapid hepatic reaccumulation of Gaucher disease (Kupffer cells containing glucosylceramide) in a patient with Gaucher disease who received a heterologous liver transplant from a donor with normal acid $\beta$-glucosidase activity (25). Thus, bone marrow-derived Kupffer cell precursors with acid $\beta$-glucosidase deficiency (i.e. Gaucher cells) repopulated the normal liver, and the hepatocellular acid $\beta$-glucosidase from the normal donor could not crosscorrect the Kupffer cell enzyme defect in this patient.
This inability of normal acid $\beta$-glucosidase to cross-correct the enzyme-deficient cells was also reflected by the enzymatic reconstitution in hepatic biopsies. Only about $40-50 \%$ of normal hepatic acid $\beta$-glucosidase activity was achieved by 419 to $735 \mathrm{~d}$ after BMT from a donor with normal, not heterozygous, levels of enzyme activity in cultured skin fibroblasts and peripheral blood lymphocytes. If acid $\beta$-glucosidase were a secreted lysosomal enzyme that could be taken up by hepatocytes, complete reconstitution of hepatic enzyme activity would have been expected. Because Kupffer cells constitute only a part of the total cellular content of hepatic biopsies, only these donor-derived cells in the present patient would contain normal enzyme levels, whereas the hepatocytes would be deficient in acid $\beta$-glucosidase activity. Thus, these two populations of cells, enzymatically normal and deficient, would average the total enzyme activity based on their numbers. This rationale might also explain the lower than normal levels of enzyme activity in lymph nodes and in lung, where the enzyme-deficient parenchymal tissues may contribute little to the determined enzyme activity (Table 4). Similar considerations apply to the selective targeting of exogenous enzyme to reticuloendothelial cells via the mannose receptor (26-28) on the surface of these cells (10-13).

In comparison to the visceral involvement, the basic etiology of the CNS manifestations in the neuronopathic variants (types 2 and 3) is poorly understood, but likely is related to the toxic accumulation of the deacylated glucosylceramide derivative, glucosylsphingosine. However, by analyzing the fatty acid acyl and sphingosyl structures of visceral and CNS glucosylceramides from affected patients, Svennerholm's group demonstrated a peripheral source of some CNS glucosylceramides and, presumably, the derived glucosylsphingosines in types 2 and 3 Gaucher disease (29). If centrally stored toxic compounds could equilibrate across the blood-brain barrier, nonpermanent CNS effects of Gaucher disease might be improved or stabilized after depletion of the peripheral pool of glucosylceramide(s). Such a mechanism may be required for efficacy of enzyme replacement therapy, because exogenously administered enzyme was not found in brain tissue of a patient who had received mannoseterminated acid $\beta$-glucosidase (13). Similarly, the acid $\beta$-glucosidase levels in brain from the present patient were in the range obtained for Gaucher disease patients (Table 4). As a result, efficacy of BMT in neuronopathic Gaucher disease also may require an equilibration or redistribution mechanism.

The clinical course, early developmental delay, and requirement for early splenectomy in the present patient were similar to those in Norrbottnian type 3 patients classified as severe by Dreborg et al. (30). Similar to our patient, these untransplanted patients had severe growth delay and required splenectomy shortly after diagnosis. Many of these Norrbottnian patients had progressive neurologic deterioration with a loss of about 30 to 50 intelligence quotient points from ages 5 to $15 \mathrm{y}$. Unfortunately, data from earlier time points were not available in that study. Our patient appeared to be following a similar but earlier pattern, and we would have expected progressive deterioration during the 24 mo of posttransplantation follow-up. No new hard neurologic signs developed in our patient after transplantation, but these are variable in the Norrbottnian patients (30). Because our patient's psychomotor development remained constant, albeit lower than normal, for the $2 \mathrm{y}$ after transplantation and no significant increase in brain enzyme level was found at autopsy, some mechanism, i.e. equilibration out of the CNS, would have to be invoked to account for her maintanence of her developmental status and prevention of further deterioration. This result was similar to that observed in two Norrbottnian type 3 patients who received BMT at about 2-3 y of age (9). However, there may be a critical threshold for CNS efficacy of BMT, inasmuch as a 9-y-old Norrbottnian type 3 patient continued slow psychomotor deterioration after successful transplantation (31). Clearly, the demonstrated efficacy of enzyme replacement therapy (1013) and BMT for Gaucher disease provide the rationale for gene 
therapy strategies via organoid or stem cell replacement approaches for the control and potential cure of Gaucher disease.

Acknowledgments. The authors thank Drs. Wendy Ludman and Marilyn Schiller for conducting the psychometric and developmental testing.

\section{REFERENCES}

1. Desnick RJ, Gatt S, Grabowski GA (eds) 1982 Gaucher Disease: A Century of Delineation and Research. Alan R Liss, Inc, New York, p 736

2. Zimran A, Gelbart T, Westwood B, Grabowski GA, Beutler E 1991 High frequency of the Gaucher disease mutation at nucleotide 1226 among the Ashkenazi Jews. Am J Hum Genet 49:855-859

3. Grabowski GA, Gatt S, Horowitz M 1990 Acid $\beta$-glucosidase: enzymology and molecular biology of Gaucher disease. Crit Rev Biochem Mol Biol 25:385414

4. Grace M, Graves PG, Smith FI, Grabowski GA 1990 Analyses of catalytic activity and inhibitor binding of human acid $\beta$-glucosidase by site-directed mutagenesis: identification of residues critical to catalysis and evidence for causality of two Ashkenazi Jewish Gaucher disease type 1 mutations. J Biol Chem 265:6827-6835

5. Grace ME, Berg A, Horowitz M, Grabowski GA 1991 Gaucher disease: heterologous expression of two alleles associated with neuronopathic phenotypes. Am J Hum Genet 49:646-655

6. Fredrickson DS, Sloan HR 1982 Glucosylceramide lipidoses: Gaucher's disease. In: Stanbury JB, Wyngaarden JB, Frederickson DS (eds) The Metabolic Basis of Inherited Disease, 3rd Ed. McGraw Hill, New York, pp 730-759

7. Rappeport JM, Ginns EI 1984 Bone marrow transplantation in severe Gaucher's disease. N Engl J Med 311:84-88

8. Hobbs JR, Hugh Jones K, Shaw PJ, Lindsay I, Handcock M 1987 Beneficial effect of pre-transplant splenectomy on displacement bone marrow transplantation for Gaucher's syndrome. Lancet 1:1111-1115

9. Erickson A, Groth CG, Mansson J-E, Percy A, Ringden O, Svennerholm L 1990 Clinical and biochemical outcome of marrow transplantation for Gaucher disease of the Norrbottnian type. Acta Paediatr Scand 79:680-685

10. Barton NW, Furbish FS, Murray GJ, Garfield M, Brady RO 1990 Therapeutic response to the intravenous infusion of glucocerebrosidase in a patient with Gaucher disease. Proc Natl Acad Sci USA 87:1913-1916

11. Barton NW, Brady RO, Dambrosia JM, DiBisceglie AM, Doppelt SH, Hill SC, Mankin HJ, Murray GJ, Parker RI, Argoff CE, Grewal RP, Yu K-T, Graham OC, Holder CA, Howard KD, Kaneski CR, Oliver KL, Riesz S, Verderese CL, Zirzow GC 1991 Replacement therapy for inherited enzyme deficiency: Macrophage-targeted glucocerebrosidase for Gaucher's disease. N Engl J Med 324:1464-1470

12. Beutler E, Kay A, Saven P, Garver D, Thurston A, Dawson A, Rosenbloom B 1991 Enzyme replacement therapy for Gaucher disease. Blood 78:11831189

13. Fallet S, Grace ME, Sibille A, Mendelson DS, Shapiro RS, Hermann G, Grabowski GA 1991 Enzyme augmentation in moderate to life-threatening Gaucher disease. Pediatr Res 31:496-502

14. Grabowski GA, Goldblatt J, Dinur T, Kruse J, Svennerholm L, Gatt S, Desnick
RJ 1985 Genetic heterogeneity in Gaucher disease: physicokinetic and immunologic studies of the residual enzyme in cultured fibroblasts from non-neuropathic and neuronopathic patients. Am J Med Genet 21:529-549

15. Najfeld V, Coyle T, Berk PD 1988 Transformation of polycythemia vera to acute nonlymphocytic leukemia accompanied by $t(1 ; 3)(\mathrm{p} 36 ; \mathrm{q} 21)$ karyotype. Cancer Genet Cytogenet 33:193-200

16. Lowry OH, Rosenbrough NJ, Farr AL, Randall RJ 1951 Protein measurement with the folin reagent. J Biol Chem 193:265-275

17. Strasberg PM, Warren I, Skomorowski MA, Lowden JA 1983 HPLC analysis of neutral glycolipids: an aid in diagnosis of lysosomal storage diseases. Clin Chim Acta 132:29-41

18. Heymsfield SB, Fulenwider T, Nordlinger B, Barlow R, Sones P, Kutner M 1979 Accurate measurement of liver, kidney and spleen volume by computerized axial tomography. Ann Intern Med 90:185-187

19. Tarao K, Hoshino H, Motohashi I, limiro K, Tamai S, Ito Y, Takagi S, Oikawa Y, Unayama S, Fujiwara T, Otagiri K, Ikeda $T$, Hayashi K, Sakurai A, Uchikishi T 1989 Changes in liver and spleen volume in alcoholic liver fibrosis of man. Hepatology 9:589-593

20. Hermann G, Goldblatt J, Levy RN, Goldsmith SJ, Desnick RJ, Grabowski GA 1986 Gaucher's disease type I: Assessment of bone involvement by CT and scintigraphy. AJR 147:943-948

21. Fleschner P, Grabowski GA, Ludman MD, Aufses A, Dolgin S 1989 Recurrence of massive splenomegaly following partial splenectomy in Gaucher disease. J Pediatr Surg 24:610-612

22. Parkman R, Rappeport JM, Hellman S, Lipton J, Smith B, Geha R, Nathan DG 1984 Busulfan and total body irradiation as antihematopoietic stem cell agents in the preparation of patients with congenital bone marrow disorders for allogenic bone marrow transplantation. Blood 64:852-857

23. Johnston Jr, RB 1988 Current concepts: immunology. Monocytes and macrophages. N Engl J Med 318:747-752

24. Kattlove HE, Williams JC, Gaynor E, Spivak M, Bradley RM, Brady RO 1969 Gaucher cells in chronic myelocytic leukemia: an acquired abnormality. Blood 331:379-385

25. Carlson DE, Busuttil RW, Guidici TA, Barranger JA 1990 Orthotopic liver transplantation in the treatment of complications of type 1 Gaucher disease. Transplantation 49:1192-1194

26. Achord DT, Brot FF, Bell CE, Sly WS 1978 Human $\beta$-glucuronidase: In vivo clearance and in vitro uptake by a glycoprotein recognition system on reticuloendothelial cells. Cell 15:269-278

27. Stahl PD, Rodman JS, Miller MJ, Schlesinger PH 1978 Evidence for receptormediated binding of glycoproteins, glycoconjugates and lysosomal glycosidases by alveolar macrophages. Proc Natl Acad Sci USA 75:1399-1403

28. Furbish FS, Steer CJ, Krett NL, Barranger JA 1981 Uptake and distribution of placental glucocerebrosidase in rat hepatic cells and effects of sequential deglycosylation. Biochim Biophys Acta 673:425-434

29. Nilsson O, Masson JE, Hakansson G, Svennerholm L 1982 The occurrence of psychosine and other glycolipids in spleen and liver from the three major types of Gaucher disease. Biochim Biophys Acta 712:453-463

30. Dreborg S, Erickson A, Hagberg B 1980 Gaucher disease; Norrbottnian type. Eur J Pediatr 133:107-118

31. Ringden O, Groth CG, Erikson A, Backman L, Granqvist S, Mansson J-E, Svennerholm L 1988 Long-term follow-up of the first successful bone marrow transplantation in Gaucher disease. Transplantation 46:66-70

32. Ludwig J 1979 Current Methods of Autopsy Practice, 2nd Ed. WB Saunders, Philadelphia, pp 676-685 